\title{
Correlation of Estradiol and Estriol Serum Levels to Melasma Severity in Pregnant Women
}

\author{
Aunur Rofiq ${ }^{*}$, SHW Tantari, A Widiatmoko and Dyah Ayu Savitri \\ Department of Dermatology and Venereology, Faculty of Medicine, Brawijaya University, RSUD Dr Saiful Anwar Malang, Indonesia
}

*Corresponding author: Aunur Rofiq, Dermatology and Venereologist, Department of Dermatology and Venereology, Dr. Saiful Anwar Hospital, Malang, East Java, Indonesia, Tel: 062818382829; E-mail: qiphor@yahoo.com

Received date: October 28, 2017; Accepted date: January 04, 2018; Published date: January 11, 2018

Copyright: (c) 2018 Rofiq A, et al. This is an open-access article distributed under the terms of the Creative Commons Attribution License, which permits unrestricted use, distribution, and reproduction in any medium, provided the original author and source are credited.

\begin{abstract}
Combination of hormonal change, ultraviolet radiation and genetics are the most responsible factors in melasma. One of pigmentation change caused by pregnancy is melasma. The critical key to describe hyperpigmentation process is increased levels of estradiol and estriol. This study is aimed to determined correlation of serum levels of estradiol and estriol to melasma severity in pregnant women. This cross-sectional study was conducted with consecutive sampling in pregnant women with melasma. This study was conducted from June to July 2017 at Dr. Saiful Anwar Regional Hospital, Malang, East Java, Indonesia. Pregnant woman with melasma (15-49 years) was included and pregnant women with the history of melasma not caused by pregnancy, which used hormonal contraception or oral hormone therapy containing estrogen and took oral phototoxic drugs, were excluded. Anamnesis, physical examination, Wood Lamp, MASI (Melasma Area and Severity Index) Score and blood was drawn to measure serum levels of estradiol and estriol by using ELISA to 25 pregnant women with melasma. Data analysis was done with Pearson correlation test and multiple linear regressions. The result showed serum levels of estradiol was significantly positive correlated with MASI Score $(r=0.462 ; p<0.05)$, but serum levels of estriol was not significantly correlated with MASI Score $(r=0.301 ; p>0.05)$. Multiple linear regression revealed $R 2=0.244(p<0.05)$, which means that serum levels of estradiol and estriol had $24.4 \%$ effects to MASI Score, while the rest $75.6 \%$ was influenced by others variables that were not included in this study. The conclusion is that there is a positive correlation between serum levels of estradiol with melasma severity in pregnant women, but serum levels of estriol are not correlated with melasma severity. Another factor besides serum levels estradiol and estriol might influence melasma severity.
\end{abstract}

Keywords: Estradiol; Estriol; Melasma severity; Pregnancy

\section{Introduction}

Melasma is also known as chloasma or mask of pregnancy [1-3] because it shows during pregnancy as a symmetrical hyperpigmented lesion $[4,5]$ Melasma patients in Indonesia was estimated to be $0.2-4 \%$ of all dermatology patients [6]. In Saiful Anwar General Hospital Malang, East Java, Indonesia, melasma was found in 338 of 9736 dermatology patients per year (3.4\%) in 2014, and is the seventh most common diagnosis in dermatology clinic. In 2015, melasma incidence was declined to 226 of 8310 patients per year and not included in the top ten most common dermatology diagnoses. The current data from Saiful Anwar General Hospital dermatology clinic in 2016 stated that melasma patient was 185 of 7945 patients per year (2.3\%).

Melasma etiopathogenesis included the genetic factor, ultraviolet exposure, and hormonal activity. The most common aetiology was the combination of genetic, hormonal status and ultraviolet radiation. Hormonal factors were pregnancy, oral contraception of estrogen replacement therapy, ovarian cancer, thyroid or ovary dysfunction, cosmetics, nutrition, phototoxic and photoallergic drugs, hepatic diseases, parasitosis and antiepileptic drugs. Pregnancy was related to several characteristic skin changes, one of them being chloasma that was related to hormonal change. Estrogen surge was the critical factor that explained hyperpigmentation in melisma [7]. This was caused by the increase of $a-\mathrm{MSH}$ (melanocyte stimulating hormone) expression in keratinocytes $[8,9]$.
Estrogen is a steroid hormone with ten carbon atoms formed mainly by androstenedione. There are three types of estrogen with more than 400 functions in the body. The three estrogen types are estrone (E1), estradiol (E2) and estriol (E3). Biologically, estradiol is the most active form. The ratio of a biological effect of those three hormones are $\mathrm{E} 2: \mathrm{E}: \mathrm{E} 3=10: 5: 1$. Estradiol potency is twelve times the potency of estrogen and eight times the potency of estriol; therefore, estradiol is said to be the main estrogen [10]. A study by Gopichandani et al. [11] supported the hypothesis that the main pathogenesis of melasma was estradiol. This was proven by the high estradiol level in pregnant women with melasma compared to those without melasma. The other forms of estrogen such as estriol and estrone also affected the cytoplasm and the main estrogen receptor known to be expressed in the melanocyte [11]. Especially in the third trimester, the high level of estriol and estradiol was related to the high level of $\mathrm{MSH}$, which caused tyrosinase and dopachrome tautomerase production; this sequence led to melanogenesis and melisma $[11,12]$.

Melasma Area Severity Index (MASI), compiled by Handel et al. in 1994 [13], was used to measure the clinical severity of melasma. The total score was related to the highest probability of clinical severity of melasma. MASI score has been used to document lesion in a clinical trial and now being used as an objective measure in trials studying the relationship between patients' quality of life and melasma severity index [13].

Miranti et al. [14] reported that serum estradiol level was higher in pregnant women with melasma versus pregnant women without 
Page 2 of 5

melasma, but this finding was statistically insignificant. Therefore, it could be concluded that serum estradiol level was related to the age of pregnant women, but not with MASI score or melasma type. There was no literature about estriol serum level, which only excreted during pregnancy, with melasma severity. This was the main reason for this study, in which we studied the correlation between serum estradiol and estriol level with melasma severity in pregnant women.

\section{Methods}

This study used cross-sectional observational analysis in Pregnancy Outpatient Clinic and Dermatology and Venereology Outpatient Clinic in Dr Saiful Anwar Regional Hospital Malang and Physiology Laboratory Faculty of Medicine Universitas Brawijaya Malang, East Java, Indonesia. The study was approved by the Hospital Ethics Committee then carried out from June to July 2016.

\section{Sample size determination}

The sample size was calculated by using single population proportion at a precision of $5 \%, 95 \%$ confidence interval and prevalence of melasma in pregnancy $43.5 \% \quad(r=0.435)$ [14]. The minimum sample size was calculated by three to add to the square of $\mathrm{Za}$ (standard normal distribution value to $\alpha$ ) $10 \%=1.282$ add $\mathrm{Z} \beta$ (standard normal distribution value to $\beta$ ) $20 \%=0.842$ divided 0.5 of 1 add $\mathrm{r}$ divided to 1 minus $\mathrm{r}$. The total minimum sample was 24 pregnant women with melasma.

\section{Patients and clinical evaluation}

The study sample was 25 outpatient pregnant women with melasma in Saiful Anwar General Hospital, Malang, East Java-Indonesia. Inclusion criteria were pregnant women with melasma, aged 15-49 years old, primigravida or multigravida and agreed to participate (agreed to sign the informed consent). Exclusion criteria were pregnant women with previous melasma not caused by pregnancy, hormonal contraception, estrogen replacement therapy, phototoxic drugs consumption (antibiotics, a non-steroidal anti-inflammatory, diuretics, retinoid, epidermal growth factor inhibitor, anti-fungal, tranexamic acid, antihistamine and neuroleptics) and twin pregnancy.

\section{Melasma severity measurement}

Melasma diagnosis and severity measurement were done by history taking and physical examination (classic findings and MASI score) by three different examiners on the same day. MASI score was measured by the sum of intensity pigmentation or darkness (D) and score of homogeneity $(\mathrm{H})$ and multiplied by with the score of area (A). MASI score measured by this formula $0.3 \mathrm{~A}$ (Forehead) $(\mathrm{D}+\mathrm{H})+0.3 \mathrm{~A}$ (Right Malar) $(\mathrm{D}+\mathrm{H})+0.3 \mathrm{~A}$ (Left Malar) $(\mathrm{D}+\mathrm{H})+0.1 \mathrm{~A}(\mathrm{Chin})(\mathrm{D}+\mathrm{H})$. The highest scores melasma is 48 and the lowest is 0 .

\section{Serum estradiol and estriol level measurement}

The blood sample was taken as much as $5 \mathrm{ml}$ and kept in a serum separator tubes (SST), then centrifuged with 2000-3000 rpm speed in $20 \mathrm{~min}$. Serum estradiol and estriol level measurement was done by ELISA method in Laboratory of Physiology, Faculty of Medicine, Brawijaya University, Malang, East Java, Indonesia.

\section{Data analysis}

Data entry was done on the data sheet. The data then processed with computer program Statistical Package for Social Sciences (SPSS). Normality test of sample data comparison was done by KolmogorovSmirnov test. To test the association between estradiol level with MASI score and between estriol levels with MASI score, we did Pearson correlation test (or Rank Spearman correlation test if data distribution was abnormal). The correlation between estradiol level and estriol level with melasma severity was tested with double linear regression.

\section{Results}

There were 25 pregnant women aged 15-49 years old with melasma included as study sample. The mean age of the sample was 32.5 years old (SD 7.77). Majority of the subjects came from age group 31-40 years old and in the third trimester. There were 21 subjects (84\%) in the first trimester, three subjects (12\%) in the second trimester and one subject (4\%) in the first trimester. As much as 18 subjects (72\%) were from Pasuruan and seven subjects (28\%) were from Malang. Sun exposure was noted in 13 subjects (52\%) with the positive family history of melasma and 12 subjects (48\%) without the family history of melasma. Based on ethnic group, Javanese was the most common ethnic group in our study, which was 16 subjects (32\%), followed by Madura (8 subjects, 16\%) and Bugis (1 subject, 2\%). Comorbidities found in the subjects were preeclampsia (4 subjects, 16\%), hyperemesis gravidarum, ventricular septal defects, asthma, macrosomia, condyloma acuminate, anemia and hepatitis B. Epidermal melasma was the most common type of melasma in our study $(17$ subjects, $68 \%$ ), followed by dermal type ( 3 subjects, $12 \%$ ) and mixed type ( 5 subjects, 20\%). Table 1 showed that there was no statistical difference in age group, place of origin, ethnic group, pregnancy stage, sun exposure duration, positive family history, comorbidities, melasma type and melasma severity score $(\mathrm{p}>0.05)$ based on Chi-square test.

\begin{tabular}{|c|c|c|c|c|}
\hline & Category & $\mathbf{N}$ & Percentage & $\begin{array}{l}\mathrm{p}- \\
\text { value }\end{array}$ \\
\hline \multirow[t]{4}{*}{ Age group } & $15-20$ years old & 2 & $8 \%$ & 0.489 \\
\hline & $21-30$ years old & 6 & $24 \%$ & \\
\hline & $31-40$ years old & 13 & $52 \%$ & \\
\hline & $41-47$ years old & 4 & $16 \%$ & \\
\hline \multirow[t]{2}{*}{ Place of origin } & Malang & 7 & $28 \%$ & 0.473 \\
\hline & Pasuruan & 18 & $72 \%$ & \\
\hline \multirow[t]{3}{*}{ Pregnancy stage } & First trimester & 1 & $4 \%$ & 0.206 \\
\hline & Second trimester & 3 & $12 \%$ & \\
\hline & Third trimester & 21 & $84 \%$ & \\
\hline \multirow[t]{2}{*}{$\begin{array}{l}\text { Sun exposure } \\
\text { duration }\end{array}$} & $<6 \mathrm{~h} /$ day & 7 & $28 \%$ & 0.861 \\
\hline & $>6 \mathrm{~h} / \mathrm{day}$ & 18 & $72 \%$ & \\
\hline \multirow[t]{2}{*}{$\begin{array}{l}\text { Timing of sun } \\
\text { exposure }\end{array}$} & $<09.00 \mathrm{am}$ & 7 & $28 \%$ & 0.861 \\
\hline & $09.00 \mathrm{am}-15.00 \mathrm{pm}$ & 18 & $72 \%$ & \\
\hline $\begin{array}{l}\text { Positive family } \\
\text { history }\end{array}$ & Yes & 13 & $52 \%$ & 0.925 \\
\hline
\end{tabular}


Page 3 of 5

\begin{tabular}{|l|l|l|l|l|}
\hline & No & 12 & $28 \%$ & \\
\hline Ethnic group & Javanese & 16 & $32 \%$ & 0.148 \\
\hline & Madura & 8 & $16 \%$ & \\
\hline Comorbidities & Bugis & 1 & $2 \%$ & \\
\hline & None & 14 & $56 \%$ & 0.399 \\
\hline & Preeclampsia & 4 & $16 \%$ & \\
\hline & $\begin{array}{l}\text { Hyperemesis } \\
\text { gravidarum }\end{array}$ & 1 & $4 \%$ & \\
\hline & VSD & 1 & $4 \%$ & \\
\hline & Asthma & 1 & $4 \%$ & \\
\hline & Macrosomia & 1 & $4 \%$ & \\
\hline & $\begin{array}{l}\text { Condyloma } \\
\text { acuminata }\end{array}$ & 1 & $4 \%$ & \\
\hline & Anemia & 1 & $4 \%$ & \\
\hline & Hepatitis B & 1 & $4 \%$ & \\
\hline Melasma type & Epidermal & 17 & $68 \%$ & $12 \%$ \\
\hline & Dermal & 3 & $20 \%$ & \\
\hline & Mixed & 5 & & \\
\hline & & & & \\
\hline
\end{tabular}

\begin{tabular}{|l|l|l|l|}
\hline Estriol and MASI score & 0.301 & 0.144 & Not significant \\
\hline
\end{tabular}

Table 3: Correlation between estradiol, estriol serum level and MASI score.

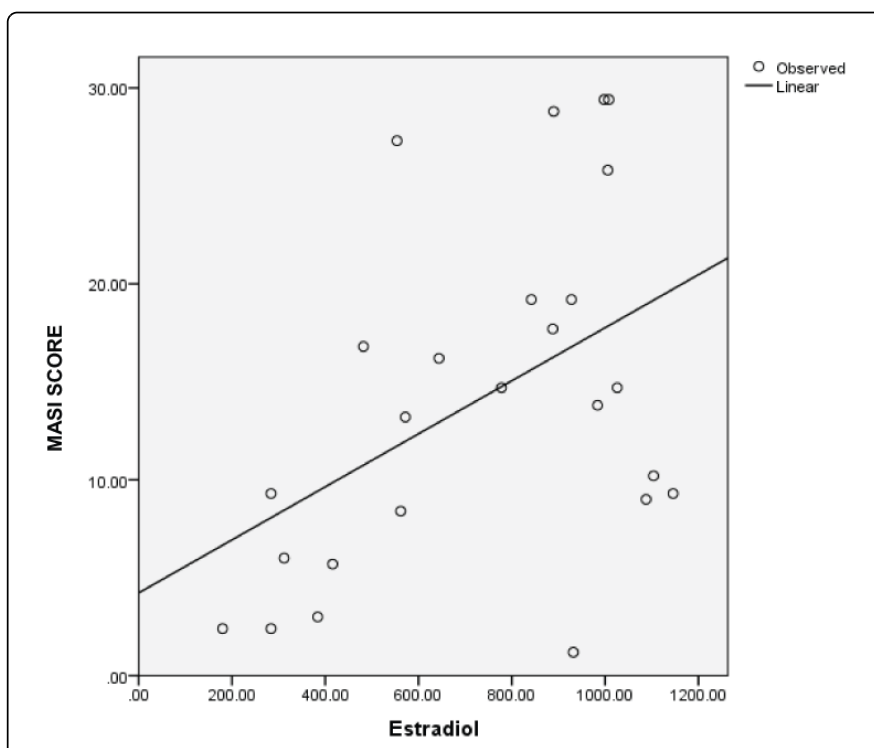

Graph 1: Graphic of correlation test between estradiol level and MASI score $(r=0.462 ; \mathrm{p}=0.020)$.

Table 1: Baseline characteristics.

The mean MASI scores mas 14.120 (SD 8.88127); the lowest score was 1.20 and the highest was 29.40 (Table 2). Mean serum estradiol level was $731.48 \mathrm{pg} / \mathrm{ml}$ (SD 303.47250); the highest level was 1145.80 $\mathrm{pg} / \mathrm{ml}$, and the lowest was $179.80 \mathrm{pg} / \mathrm{ml}$. The mean serum estriol level was $141.176 \mathrm{pg} / \mathrm{ml}$ (SD 98.69529) with the highest level of 303.80 $\mathrm{pg} / \mathrm{ml}$ and the lowest level was $8.20 \mathrm{pg} / \mathrm{ml}$.

\begin{tabular}{|l|l|l|l|}
\hline & Lowest & Highest & Mean \pm SD \\
\hline MASI score & 1.2 & 29.4 & $14.1240 \pm 8.88127$ \\
\hline Estradiol $(\mathrm{pg} / \mathrm{ml})$ & 179.8 & 1145.8 & $731.4800 \pm 303.47250$ \\
\hline Estriol $(\mathrm{pg} / \mathrm{ml})$ & 8.2 & 303.8 & $141.1760 \pm 98.69529$ \\
\hline
\end{tabular}

Table 2: MASI score, estradiol and estriol serum level.

Data distribution was normal; therefore, Pearson correlation test was done. The Pearson test revealed the correlation between estradiol level and MASI score as correlation coefficient $0.462(\mathrm{r}=0.462)$, with a significance level of $0.020(\mathrm{p}<0.05)$. Therefore, it could be stated that there was a significant correlation between estradiol level and MASI score (Table 3). This analysis result was presented as linear graphic (Graph 1). Based on Sujarweni study on 2015, the correlation coefficient 0.41-0.7 was categorized into moderate correlation [15-17].

\begin{tabular}{|l|l|l|l|}
\hline Variables & $\mathbf{r}$ & $\mathbf{p}$-value & Interpretation \\
\hline Estradiol and MASI score & 0.462 & 0.02 & Significant \\
\hline
\end{tabular}

Linear regression test between estradiol and estriol level with MASI score showed R2 $=0.244$ with $\mathrm{p}$-value $=0.046(\mathrm{p}<0.05)$ for estradiol and $\mathrm{p}=0.360$ for estriol. This means estradiol and estriol level has an effect on MASI score as much as $24.4 \%$ and the rest $75.6 \%$ was affected by other variables not included in this study.

\section{Discussion}

Melasma lesion was categorized into two basic types, i.e. epidermal and dermal type. In epidermal type, there was melanin deposition in the basal and suprabasal layer of the epidermis, and melanocytes were pigmented with many dendrites. In dermal type, there was perivascular melanophage at the superficial dermal and deep dermal layer, with little pigmentation in the epidermal layer [18]. In our study, the most common melasma type was epidermal (68\%), mixed (20\%), and dermal (12\%). The mean estradiol level, estriol level and MASI score were highest in dermal type melasma, although it was statistically insignificant. This finding differed from a study result of Miranti et al. [14] that reported mixed type was the most common type. The study explained that melasma type was correlated with the bonding of estrogen receptor and estradiol.

Estrogen receptor b was recently found in human epidermis and also in papillary dermis and vascular area, while ER- $\alpha$ (classic estrogen receptor) was not found in the epidermis. ER- $\alpha$ was mostly found in reproductive system, while ER- $\beta$ could be found in reproductive system and other organs such as skin. Estradiol was bound to both of these receptors with the same affinity. However, recent studies showed that heterodimer could happen in these two receptors in vitro, so there was a possibility of cooperative, synergic, or inhibitive mechanism between these receptors [18]. Difference in these studies results could be caused by several reasons. Other mechanisms in the estrogen 
receptors of pregnant women and the role of high-level estradiol and estriol in those receptors were not known yet.

The mean level of estradiol was $731.48 \mathrm{pg} / \mathrm{ml}$ with the highest level of $1145.80 \mathrm{pg} / \mathrm{ml}$ and the lowest of $179.80 \mathrm{pg} / \mathrm{ml}$. The mean level of estriol was $141.176 \mathrm{pg} / \mathrm{ml}$ with the highest level of $303.80 \mathrm{pg} / \mathrm{ml}$ and the lowest level of $8.20 \mathrm{pg} / \mathrm{ml}$ (Table 3). In this study, we found a significant correlation between estradiol level and MASI score $(\mathrm{r}=0.462 ; \mathrm{p}=0.020)$, but there was no significant correlation between estriol level and MASI score $(\mathrm{r}=0.301 ; \mathrm{p}=0.144)$. Base on correlation level, the correlation coefficient 0.462 in this study was classified as moderate correlation. In the linear regression graphic, it could be seen that was a positive correlation coefficient between estradiol level and MASI score; therefore, the higher the estradiol level, the higher the MASI score was, and vice versa. In this study, estriol level was also increased, but it was statistically insignificant correlated with MASI score $(\mathrm{p}>0.05)$. Another study supporting this finding was a study by Miranti et al. [14] that reported the relation of estradiol level in pregnant women with melasma versus level in pregnant women without melisma. The Miranti et al.s [14] study found the difference of estradiol level between the two groups, but it was statistically insignificant. There were no other studies that measure estriol level in pregnant women with melasma to support our findings. Several kinds of literature explained how estrogen in pregnancy worked.

During pregnancy, estradiol level increased greatly until the end of pregnancy; commonly, the level reached $20,000 \mathrm{pg} / \mathrm{ml}$ [10]. Estradiol was synthesized from progesterone via pregnenolone, which was a derivative of cholesterol. Estradiol was an estrogen receptor (ER) agonist, a steroid receptor in nucleus. ER was classified into 2 subtypes, ER- $\alpha$ and ER- $\beta$. Estradiol had high affinity; therefore it activated the two receptors potently. ER activation triggered the modulation of gene transcription and expression in cells that expressed those receptors. Estradiol also worked as an estrogen receptor agonist in cell membrane, such as G-protein-coupled estrogen receptor (GPER) and other non-nucleated receptors found recently, and also have several other non-genomic effects rapidly [19]. Differed from ER, GPER was selective to estradiol and had a very low affinity for other endogenous estrogens (such as estrone and estriol) [19]. Biological effect of estradiol was mediated by ER- $\alpha$ and ER- $\beta$ expressed in human skin [18]. Estradiol was considered as the most active form of estrogen and had a high potency for melanogenesis, melanocytosis and melanin pigment deposition [20].

Physiologic function of estriol had not been fully understood. Estriol was a short-acting estrogen and had the lowest affinity to ER- $\alpha$ and ER- $\beta$ compared to estradiol and estrone. Estriol was rapidly released from its bond with activated estrogen receptor [21,22]. A study by Falah et al. [22] stated that in pre-menopaused non-pregnant women, estriol was the result of estradiol and estrogen metabolism product in the liver. Ovary follicles and luteal corpus also produced estriol in small amount. In pregnancy, estriol was produced by fetus from 16-hydroxylation dehydroepiandrosterone (16-OH-DHEA), which was metabolized by sulphate steroid in placenta. From the placenta, $90 \%$ of estriol was carried to maternal circulation, where unconjugated estriol was carried to the liver and converted by glucuronic transferase enzyme to a more soluble form, then excreted to urine. As much as $80-90 \%$ of estriol was converted to conjugated glucuronic acid and $10-15 \%$ still being unconjugated estriol. Unconjugated estriol life cycle in maternal circulation was 20-30 min. In pregnancy, the mean urinary estriol concentration would start to increase in 12 weeks and continued to increase throughout the pregnancy. Estriol in maternal circulation was formed by conjugation of estriol, whereas unconjugated estriol was formed fully by fetoplacental unit. Therefore it was more sensitive as fetus health indicator $[22,23]$.

Even though estriol had the lowest affinity to estrogen receptor among all estrogens, there were several theories stated the mechanism of estriol and estradiol. Kroumpouzos and Cohen in 1984 [24] indicated estriol could compete with estradiol to bond with estrogen receptor in the uterus. This theory was supported by data of difference in estradiol and estriol level physiologically. In a physiologic manner, estriol production was controlled by estradiol production; however, in pregnancy estriol production was no longer dependent on estradiol and estriol level was high at the end of the pregnancy. In melasma pathogenesis, high estrogen would bind to estrogen receptor in melanocyte, stimulating the melanin production. The higher the estrogen level, the higher the melanin production and melasma incidence. Estrogen level in pregnant women was dominated by estradiol (E2) and estriol (E3) form. In our study, estradiol was correlated with melasma severity, but not in estriol. This could be explained by higher affinity of estradiol than estriol. The theory of Kroumpouzos and Cohen could also support the finding of a correlation between estradiol level and melasma severity [24].

Linear regression test found that estradiol and estriol had an effect on MASI score as much as $24.4 \%$ and the rest of $75.6 \%$ was the result of other variables not included in this study. This finding was supported by a theory of Costin and Birlea, 2006, which stated hormone factors as not the only one-factor causing melasma in pregnancy; instead, there were other factors such as genetic, hormonal, and ultraviolet radiation [25].

In this study, there were several shortcomings that potentially caused bias. This study sample size was too small so that bigger sample size future study will be needed. The method in measuring melasma severity was subjective and depended on examiner; although, this risk was reduced by using three examiners. A more objective method to determine melasma severity was needed, such as mexameter or chroma meter. Besides, melasma was a localized hyperpigmentation disorder in the face, but the estradiol an estriol measurement was taken from a blood sample. Therefore, histopathology studies may be needed. Subjectivity and study methods, including sample extraction, measurement, data gathering, and analysis, could affect the study validity.

\section{Conclusion}

Serum estradiol level was significantly correlated with melasma severity in pregnant women. This correlation was not found with estriol level. Estradiol and estriol level had $24.4 \%$ impact on MASI score; the rest of $75.6 \%$ was the result of other variables not included in this study, such as genetic factor or sun exposure.

\section{References}

1. Newcomer VD, Lindbert MC, Stenbert TH (1961) A melanosis of the face ("chloasma"). Arch Dermatol 83:284-297.

2. Soepardiman L (2007) Kelainan Pigmen. In: Djuanda A, Hamzah M (eds.) Ilmu Penyakit Kulit dan Kelamin. Jakarta: Balai Penerbit FKUI, pp: 289-292.

3. Lee DJ, Lee J, Ha J,Park KC, Ortonne JP (2012) Defective barrier function in melasma skin. J Eur Acad Dermatol Venereol 26: 1533-1537. 
Citation: Rofiq A, Tantari SHW, Widiatmoko A, Savitri DA (2018) Correlation of Estradiol and Estriol Serum Levels to Melasma Severity in Pregnant Women. J Dermatol Dis 5: 268. doi:10.4172/2376-0427.1000268

Page 5 of 5

4. Grawkrodjer DJ (2002) Pigmentation. Dermatology an illustrated colour text. British: Crurchill Livingstone, p: 70-71.

5. Hindritiani R (2015) Melasma. In: Toruan S (eds.) Skin Pigmentation. Study Group of Cosmetic Dermatology Indonesia, pp: 114-125.

6. Prakoeswa S (2002) Colorimetric measurements and light sensitivity from ultraviolet light of the three variants of the skin color of Indonesia: light brown, moderate and dark brown. Fakultas Kedokteran Universitas Airlangga.

7. Beckmann CRB, Ling FW, Barzansky BM, Herbert WNP, Laube DW, et al. (2010) Maternal fetal physiology in obstetric and gynecology. Sixth Edition. Baltimore, p: 51.

8. Im S, Kim J, On WY, Kang WH (2002) Increased expression of alpha melanocyte stimulating hormone in the lesional skin of melasma. Br J Dermatol 146:165-167.

9. Pandya A, Berneburg M, Ortonneà JP, Picardo M (2007) A global survey of the role of ultraviolet radiation and hormonal influences in the development of melasma. Br J Dermatol 156:21-28.

10. Speroff L, Glass RH, Kase NG (2005) Menopause and perimenopausal transition. In: Wilkins LW (eds.) Clin Gynecol Endocrinol Infertil Phila 643-647.

11. Gopichandani K, Arora P, Garga U, Bhardwaj M, Sharma N, et al. (2015) Hormonal profile of melasma in Indian females. Pigment Int 8590.

12. Goglia B, Gianfaldoni S (2014) Melasma: A cosmetic stigma during pregnancy. Pigmentary Disorders S1:007.

13. Handel AC, Miot LDB, Miot HA (2014) Melasma: a clinical and epidemiological review. Ann Braz Dermatol 89:771-782.

14. Miranti A, Anwar A, Djawad K, Pattelongi I, Wahab S, et al. (2016) Analysis level of serum estradiol hormone of pregnant women with melasma. Am J Clin Exp Med 4:26-29.
15. Sujarweni VW (2015) Metodologi penelitian bisnis and ekonomi. Yogyakarta: Pustaka Baru Press.

16. Rodrigues M, Ayala-Cortés AS, Rodríguez-Arámbula A, Hynan LS, Pandya AG (2016) Interpretability of the modified melasma area and severity index (mMASI). JAMA Dermatol 152: 1051-1052.

17. Sanchez NP, Pathak MA, Sato S, Fitzpatrick TB, Sanchez JL, et al. (1981) Melasma: A clinical, light microscopic, ultrastructural and immunofluorescence study. J Am Acad Dermatol 4: 698-710.

18. Thornton MJ (2002) The biological actions of estrogens on skin. Exp Dermatol 11: 487-502.

19. Prossnitz ER, Barton M (2014) Estrogen biology: New insights into GPER function and clinical opportunities. Mol Cell Endocrinol 389: 71-83.

20. Rakhmawati D (2013) Pengaruh kadar estradiol basal terhadap melasma. Universitas Gadjah Mada.

21. Watson CS, Jeng YJ, Kochukov MY (2008) Non-genomic actions of estradiol compared with estrone and estriol in pituitary tumor cell signaling and proliferation. Federat Am Soc Exp Biol J 22: 3328-3336.

22. Falah N (2015) Estriol review: Clinical applications and potential biomedical importance. Clin Res Trials 1: 29-33.

23. Damevska K (2014) New aspects of melasma. Serb J Dermatol Venereol 6: 5-18.

24. Kroumpouzos G, Cohen C (2001) Dermatoses of pregnancy. J Am Acad Dermatol 45: 1-19.

25. Costine GE, Birlea SA (2006) What is the mechanism for melasma that so commonly accompanies human pregnancy? IUBMB Life 58: 55-57. 